Marzena BuchnAT

ORCID 0000-0002-7579-6715

ANETA WOJCIECHOWSKA

ORCID 0000-0003-2716-3507

Uniwersytet im. Adama Mickiewicza

$w$ Poznaniu

\title{
RODZEŃSTWO OSÓB Z NIEPEŁNOSPRAWNOŚCIĄ W SYTUACJI KRYZYSOWEJ WYWOŁANEJ PANDEMIĄ WIRUSA COVID-19
}

\begin{abstract}
AвstRAct. Buchnat Marzena, Wojciechowska Aneta, Rodzeństwo osób z niepetnosprawnością w sytuacji kryzysowej wywołanej pandemia wirusa COVID-19 [Siblings of People with Disabilities in a Crisis Situation Caused by Covid-19 Pandemic]. Studia Edukacyjne nr 57, 2020, Poznań 2020, pp. 33-46. Adam Mickiewicz University Press. ISSN 1233-6688. DOI: 10.14746/ se.2020.57.3
\end{abstract}

The situation of a virus SARS - CoV-2 pandemic, which has been causing COVID-19 disease, is for everyone a new and unknown situation leading to fear and insecurity. It is also the situation which caused a lot of changes in many people's daily routine.

The aim of this article is to point out the specific difficulties which child and youth siblings of people with disabilities in everyday life as a crisis situation caused by the pandemic. The purpose of this article is also to indicate the capabilities of supporting this social group.

This text has been written in methodical and practical capacity in order to inspire disscussion and research in this area.

Key words: siblings of people with disabilities, crisis, COVID-19

\section{Wprowadzenie}

Specyficzna sytuacja, w jakiej znalazło się całe społeczeństwo z powodu pandemii wirusa SARS-CoV-2, który wywołuje chorobę COVID-19, spowodowało dezintegrację codziennego życia. Ta trudna sytuacja budzi lęk i wywołuje wiele negatywnych emocji, z którymi wszyscy próbują sobie radzić. W najtrudniejszej sytuacji znajdują się jednak dzieci i młodzież, dla której kryzys związany z pandemią nakłada się na inne kryzysy, jakich doświadczają 
w swoim życiu. Taką grupę stanowi rodzeństwo osób z niepełnosprawnością, którzy muszą codziennie stawiać czoła sytuacji trudnej związanej z posiadaniem brata czy siostry z niepełnosprawnością. Pogłębienie się sytuacji kryzysu rodzinnego, a także nachodzące na niego nowe sytuacje trudne związane z pandemią, jak na przykład lęk, izolacja, mogą powodować, że obciążenie psychiczne, jak i fizyczne tych dzieci będzie zbyt duże, aby mogły sobie z nim same poradzić. W takim przypadku niezbędne może okazać się zastosowanie różnego rodzaju wsparcia.

\section{Rodzeństwo osób z niepełnosprawnością}

Sytuacja rodzeństwa osób z niepełnosprawnością jest bardzo złożona i zróżnicowana. Pojawianie się dziecka $z$ niepełnosprawnością $w$ rodzinie zmienia ją we wszystkich płaszczyznach, ponieważ rodzina jako system tworzy splot specyficznych wzajemnych relacji, łączących jej poszczególnych członków w taki sposób, że zmiana jednego elementu prowadzi do istotnych zmian $\mathrm{w}$ całości układu ${ }^{1}$. Wymusza przeformułowanie celów życiowych jej wszystkich uczestników.

W związku z tym fakt posiadania niepełnosprawnego brata czy siostry nie pozostaje obojętny również dla funkcjonowania reszty rodzeństwa. $Z$ jednej strony wzbogaca on ich rozwój poprzez wykształcenie wielu nowych kompetencji, z drugiej strony generuje jednak wiele sytuacji trudnych, obciążających psychicznie jak i fizycznie. Wskazuje się, że posiadanie niepełnosprawnego rodzeństwa może stanowić czynnik stymulujący rozwój zdrowego rodzeństwa, choćby poprzez specyficzne doświadczenia życiowe niedostępne dla osób żyjących w rodzinach bez osób z niepełnosprawnością. Niektórzy z nich stają się bardziej odpowiedzialni, samodzielni, dojrzali pod względem społecznym, wrażliwi na potrzeby innych, deklarujący większą akceptację i zrozumienie dla odmienności². Wychowywanie się w większej rodzinie $\mathrm{z}$ dzieckiem z ASD, z licznym rodzeństwem rozwijającym się prawidłowo, zmniejsza skutki dorastania w rodzinie z dzieckiem z ASD. Badacze wskazują także, że $\mathrm{w}$ takich rodzinach pojawia się więcej pozytywnych odczuć, a u rodzeństwa można także dostrzec więcej zachowań adaptacyjnych ${ }^{3}$.

${ }^{1}$ Z. Dołęga, System rodzinny a samotność dzieci i młodzieży, [w:] Kultura pedagogiczna wspótczesnej rodziny, red. J. Cichla, J. Herberger, B. Skwarek, Głogów 2010, s. 205-217.

${ }^{2}$ E. Pisula, Rodzice i rodzeństwo z zaburzeniami rozwoju, Warszawa 2007, s. 202; A. Żyta, Badania nad rodzeństwem osób z niepetnosprawnościa intelektualna w perspektywie zmian - przeszłość, teraźniejszość, przyszłość, [w:] Pedagogika specjalna: różne poszukiwania - wspólna misja, red. M. Bielska-Łach, Warszawa 2009, s. 372-380.

${ }^{3}$ L. Kaminsky, D. Dewey, Psychosocial adjustment in siblings of children with autism, Journal of Child Psychology and Psychiatry and Allied Disciplines, 2002, 43, 2, s. 225-232. 
Z drugiej strony, stanowi czynnik obciążający rozwój i sposób funkcjonowania pełnosprawnego rodzeństwa. Rodzice $w$ sytuacji pojawienia się niepełnosprawnego dziecka sami znajdują się w sytuacji kryzysowej, w związku z czym często nie podejmują rozmów ze swoimi dziećmi na temat choroby ich brata czy siostry. Ten brak rozmów czy szczerego wyrażania przeżywanych emocji powoduje u zdrowego rodzeństwa poczucie lęku, napięcia w zaistniałej sytuacji ${ }^{4}$. Rodzice przez wzmożone potrzeby dziecka z niepełnosprawnością mają znacznie mniej czasu dla swoich pełnosprawnych dzieci. Ograniczony czas na rozmowy, wspólne bycie ze sobą, czy pomoc w różnych czynnościach, na przykład lekcjach, może powodować, że rodzeństwo osób z niepełnosprawnością czuje się zaniedbywane przez swoich rodziców. Taki długotrwały stan dzieci te odbierają często jako ignorancję ze strony rodziców ich potrzeb, jak również ich samych, co w konsekwencji może prowadzić do odczucia, że są mniej ważni dla swoich rodziców. Poczucie krzywdy kształtuje u nich przekonanie o uprzywilejowanej pozycji niepełnosprawnego rodzeństwa. Postrzegają oni rodziców (głównie matki) jako zbyt pobłażliwych i nadopiekuńczych względem swojego brata czy siostry z niepełnosprawnością. Takiemu postrzeganiu pozycji brata czy siostry z niepełnosprawnością towarzyszy zmiana pozycji i pełnionych ról przez pełnosprawne rodzeństwo. W przypadku pełnionych ról występuje zjawisko poszerzania, jak i pomieszania ról. $W$ zakresie poszerzania ról od rodzeństwa osób z niepełnosprawnością często oczekuje się pomocy w zakresie opieki, pielęgnacji, zabawy, nauki ze swoim rodzeństwem, czy przejęcia obowiązków domowych. Do pomieszania ról dochodzi w sytuacji, gdy młodsze rodzeństwo osób z niepełnosprawnością przyjmuje ich role, której oni nie są $\mathrm{w}$ stanie sami realizować.

Takie oczekiwania wiążą się często z nadmiernym przeciążeniem fizycznym, jak i psychicznym związanym z poczuciem odpowiedzialności za drugą osobę. Obciążające dla zdrowego/pełnosprawnego rodzeństwa jest również radzenie sobie $z$ trudnymi i często niezrozumiałymi zachowaniami brata czy siostry z niepełnosprawnością. Zachowanie to, odbiegające od przyjętych norm społecznie, powoduje między innymi trudności w akceptacji niepełnosprawnego rodzeństwa przez otoczenie, co niestety może również determinować problemy w kontaktach z rówieśnikami ich pełnosprawnych barci/ sióstr ${ }^{5}$. Rodzeństwo z racji nieumiejętności lub często braku wiedzy nie potrafi wyjaśnić swoim rówieśnikom przyczyn specyficznego zachowania ich brata/siostry z niepełnosprawnością. Może to powodować unikanie kontaktów

\footnotetext{
${ }^{4}$ S.A. Clarke i in., Parental communication and children's behaviour following diagnosis of childhood leukaemia, Psycho-Oncology, 2005, 14, s. 274-281.

${ }^{5}$ A. Żyta, Rodzeństwo osób z głębszą niepetnosprawnościa intelektualną, Kraków 2004.
} 
z rówieśnikami w obawie przed odrzuceniem bądź wyśmianiem ze strony kolegów czy koleżanek 6 .

Z uwagi na takie obciążenie psychiczne, jak i fizyczne tych dzieci, ich dobrostan jest poważnie zagrożony. Na podstawie przeprowadzonych badań ujawniono, że rodzeństwo osób z niepełnosprawnością cechuje wyższy poziom lęku, tendencje do wycofywania się z kontaktów interpersonalnych, a także większe skłonności depresyjne niż braci i sióstr osób prawidłowo rozwijających się?

Zatem, na podstawie licznie przeprowadzonych badań ${ }^{8}$ można stwierdzić, że rodzeństwo osób z niepełnosprawnością będące w normie rozwojowej jest często niedostosowane. Charakteryzuje się wyższym poziomem ryzyka wystąpienia zaburzeń emocjonalnych, problemów adaptacyjnych czy społecznych $\mathrm{w}$ obszarze trudności w nawiązywaniu prawidłowych relacji z rówieśnikami ${ }^{9}$.

Warto również zwrócić uwagę, że rodzeństwu w normie rozwojowej towarzyszą ambiwalentne uczucia związane z własną przyszłością. Jako że poczucie odpowiedzialności za rodzeństwo z niepełnosprawnością często towarzyszy im już przez całe życie ${ }^{10}$, zastanawiają się, jaką rolę będą pełnić w przyszłości w opiece nad bratem/siostrą.

Na ile pojawienie się brata czy siostry z niepełnosprawnością będzie wzbogacające lub obciążające rozwój pełnosprawnego rodzeństwa, zależy również od wielu czynników: wieku (zarówno jednego, jak i drugiego dziecka), kolejności narodzin, różnicy wieku między rodzeństwem, liczby dzieci w rodzinie, rodzaju i nasilenia niepełnosprawności, występujących zachowań problemowych (trudnych), wsparcia rodziny, postaw rodziców, ale także od pochodzenia kulturowego, religii, czy wyznawanych wartości w rodzinie ${ }^{11}$.

${ }^{6}$ E. Pisula, Rodzice i rodzeństwo dzieci z zaburzeniami rozwoju; J. Prata, W. Lawson, R. Coelho, Stress factors in parents of children on the autism spectrum: an integrative model approach, International Journal of Clinical Neurosciences and Mental Health, 2019, 6, 2.

${ }_{7}$ S. Fisman i in., Longitudinal study of siblings of children with chronic disabilities, Canadian Journal of Psychiatry, 2000, 45(4), s. 369-375.

${ }^{8}$ Między innymi: D. Sharpe, L. Rossiter, Siblings of Children with a Chronic Illness: A Meta-Analysis, Journal of Pediatric Psychology, 2002, 8, s. 699-710; I.R. Vermaes, A.M. Susante, H.J. Bakel, Psychological Functioning of Siblings in Families of Children with Chronic Health Conditions: A Meta-Analysis, Journal of Pediatric Psychology, 2012, 37, s. 166-184; A. Żyta, Rodzeństwo osób z głębszą niepetnosprawnościa intelektualna; S.M. McHale, K.A. Updegraff, M.E. Feinberg, Siblings of Youth with Autism Spectrum Disorders: Theoretical Perspectives on Sibling Relationships and Individual Adjustment, Journal of Autism and Developmental Disorders, 2016, 46(2), s. 589-602.

${ }^{9}$ K. Walęcka-Matyja, A. Przybylak, Sytuacja życiowa rodzeństwa osób z niepetnosprawnościa intelektualna, [w:] Rozwój i jego wspieranie w perspektywie rehabilitacji i resocjalizacji, red. D. Müller, A. Sobczak, Łódź 2013, s. 73.

${ }^{10}$ K. Ley, Rodzeństwo - miłość, nienawiść, solidarność, Warszawa 2004, s. 183.

${ }^{11}$ A. Żyta, Rodzeństwo osób z niepetnosprawnością. Wspólne dorastanie. Dylematy. Wsparcie, [w:] Rodzeństwo osób z niepetnosprawnościa, red. J. Koral, Warszawa 2013. 
Bez względu na układ tych czynników należy jednak zawsze zwracać uwagę na wysoką złożoność zagadnienia funkcjonowania rodzeństwa osób z niepełnosprawnością i ich trudną sytuację w jakiej się znaleźli.

\section{Sytuacja kryzysowa}

W życiu każdego człowieka pojawiają się sytuacje wywołujące stres. Jednych motywuje do dalszego działania, doprowadza do reorganizacji życia i mobilizuje do zmian w życiu, drugich zatrzymuje, dekompensuje, demobilizuje, a często doprowadza do poważnych stanów emocjonalnych, lękowych, depresyjnych, które nie pozwalają postępować dalej. Zmienia na tyle poprawne funkcjonowanie człowieka, że doprowadza do kryzysu, a więc sytuacji wywołujących skrajne emocje, gniew, złość, poczucie żalu i bezradności.

Kryzys, według H. Skłodowskiego, to element narastającej sytuacji zagrożenia, która jest dla jednostki nowa, zaskakująca, wiążąca się z utratą kontroli, mogąca być stanem prawdziwym bądź jedynie odczuwalnym ${ }^{12}$. Kryzys może być rozpatrywany na różne sposoby: 1) jako utrata bądź zachwianie równowagi psychicznej; 2) jako brak bądź zablokowanie strategii zaradczych i obronnych adekwatnych do zaistniałej sytuacji; 3) jako moment przełomowy, dający podstawy do podejmowania zmian w życiu; 4) jako zagrożenie „ja" oraz 5) jako zagrożenie dotychczasowego systemu wartości ${ }^{13}$.

Kryzys można scharakteryzować na różne sposoby. Należy rozpatrywać go jako zjawisko wielowymiarowe, złożone i niejednolite w swoim przebiegu i strukturze. Pewnych prób jego opisu dokonali R.K. James oraz B.E. Gilliland. Wskazali oni, że jak w poprzednim ujęciu może być z jednej strony zagrożeniem dla funkcjonowania jednostki w różnych sferach życia, tak z drugiej strony może stanowić szansę na samorozwój i samorealizację w wyniku podjętych interwencji w pracy nad kryzysem. Tej zmianie może towarzyszyć lęk, który mobilizuje do działania i doprowadza do pozytywnych wymiarów pracy nad kryzysem. Jednostka mobilizuje się do podejmowania wyborów, co daje szansę na ruszenie z miejsca, w którym się znajduje. Najczęściej nie ma jednak prostych rozwiązań ani panaceum. Poprawa sytuacji nie przychodzi szybko, wymaga podejmowania wielu działań, których celem jest także dotarcie do bodźca wywołującego kryzys. Do cech kryzysu autorzy zaliczają także jego uniwersalność, co oznacza w pewnych okolicznościach, że nikt nie jest na niego odporny i nie ma pewności, że nigdy nie doświadczy go we wła-

${ }^{12}$ H. Skłodowski, Psychologiczne wyzwania kryzysu, [w:] Człowiek w kryzysie - psychospołeczne aspekty kryzysu, red. H. Skłodowski, Łódź 2010.

${ }^{13}$ E. Włodarczyk, Zdarzenie losowe i sytuacja kryzysowa, [w:] Człowiek wobec krytycznych sytuacji życiowych. Z teorii i praktyki pracy socjalnej, red. E. Włodarczyk, I. Cytlak, Poznań 2011, s. 356. 
snym życiu. Trudno także mówić o przyczynach kryzysu. Nie ma tu prostej reguły przyczyna - skutek. Na jego pojawienie się może bowiem wpływać wiele czynników, które na siebie oddziałują i wzajemnie splatają ${ }^{14}$.

Kryzys nie pojawia się nagle, jak też nie znika nagle. Jego przebieg można wyrazić w kilku fazach:

1) szoku (niezgodności), w której występuje niezgodność pomiędzy dotychczasowymi celami a aktualnymi zasobami i możliwościami człowieka. Pojawiają się lęk, niepokój oraz przeświadczenie, że dotychczasowe źródła wsparcia i pomocy są niewystarczające, aby rozwiązać sytuację, w której znalazła się jednostka. Zasoby indywidualne także zawodzą, co prowadzi do przejścia do fazy drugiej;

2) reakcji emocjonalnej - poczucia utraty kontroli, w której osoba nie widzi szansy i możliwości rozwiązania trudności. Pojawia się poczucie przegranej, a to powoduje wzrost napięcia;

3) mobilizacji, kiedy jednostka uruchamia wszelkie swoje zasoby w celu przezwyciężenia bądź rozwiązania kryzysu;

4) pojawiającej się jako ostatnia, jeśli w poprzedniej fazie nie udało się rozwiązać kryzysu. Doprowadza do dekompensacji. Jednostka zaczyna doświadczać chaosu, problemów z postrzeganiem rzeczywistości. Rozpoczyna wycofywanie się z kontaktów społecznych, może popaść w uzależnienia, reagować złością, agresją i autoagresją ${ }^{15}$. W innym ujęciu faza ta może być także ujmowana jako faza nowej orientacji, w której dochodzi do stopniowej odbudowy poczucia własnej wartości, poszukiwania i podejmowania nowych aktywności. Jest to także faza, w której następuje zmiana sposobu myślenia o sobie, przyjmowania nowych ról, wzbogacania doświadczeń życiowych $^{16}$.

Kryzysy sytuacyjne (losowe) wywoływane są zdarzeniami nagłymi, nieoczekiwanymi i niespodziewanymi. Zagrażają one życiu i zdrowiu człowieka, a także poczuciu bezpieczeństwa. Jak zauważa E. Włodarczyk, kluczem odróżniającym kryzys sytuacyjny od innych jest jego nagłość, szokujący charakter, intensywność i katastroficzność.

Przyczyn kryzysu można doszukiwać się w wielu czynnikach. Najczęściej jest ich kilka, jednak zauważa się, że jeden z nich dominuje i stanowi podstawę wystąpienia owego kryzysu. Kryzys jest etapem sytuacji kryzysowej,

${ }^{14}$ R.K. James, B.E. Gilliland, Strategie interwencji kryzysowej, Warszawa 2004, zob. też: J. Jezierska, Diagnoza w obszarze interwencji kryzysowej, Lubelski Rocznik Pedagogiczny, 2019, XXXVIII, 2, s. 191-204.

15 R.J. Gerrig, P.G. Zimbardo, Psychologia i życie, Warszawa 2006; W. Badura-Madej, Podstawowe pojęcia teorii kryzysu i interwencji kryzysowej, [w:] Wybrane zagadnienia interwencji kryzysowej. Poradnik dla pracowników socjalnych, red. W. Badura-Madej, Katowice 1999, s. 15-23; K. Sygulska, M. Krupska, Kryzys w życiu człowieka, Praca Socjalna, 2019, 6, s. 93-108.

${ }^{16}$ E. Włodarczyk, Zdarzenie losowe i sytuacja kryzysowa. 
która najczęściej stanowi następstwo zagrożenia, niepokoju społecznego, katastrofy naturalnej czy technologicznej. Kryzys przemiany ma związek z fundamentalnymi wydarzeniami w życiu człowieka, jak na przykład ślub, urodzenie dziecka i tym podobne. Natomiast, kryzys chroniczny nazywany jest stanem ",transkryzysowym”, którego doświadczają jednostki o takich charakterystycznych cechach osobowości, jak wycofanie się z kontaktów, bierność, brak motywacji do podejmowania działania.

W sytuacji braku możliwości przystosowania się do zaistniałego kryzysu, jednostka może przybrać, jak wskazuje J. Jezierska, cztery strategie. Pierwszą jest samodzielne pokonywanie trudności. Druga to "pozorne uporanie się z kryzysem", co wiąże się z przekierowaniem własnej aktywności na inne działanie, wyparcie sytuacji trudnej, czy deprecjonowanie danego wydarzenia. Trzecia strategia polega na braku radzenia sobie z sytuacją, co prowadzi do załamania psychicznego. Czwarta z kolei zawiera się w umiejętnym szukaniu pomocy i wsparcia ze strony najbliższego środowiska ${ }^{17}$.

W doświadczaniu kryzysu i prób przezwyciężenia trudnej sytuacji znaczenie ma poczucie koherencji jednostki. Koncepcja, której autorem jest A. Antonovsky, określa ją jako

globalną orientację człowieka, wyrażającą stopień, w jakim człowiek ten ma dominujące, trwałe, choć dynamiczne poczucie pewności, że: 1) bodźce napływające w ciągu życia ze środowiska wewnętrznego i zewnętrznego mają charakter ustrukturowany, przewidywalny i wytłumaczalny; 2) dostępne są zasoby, które pozwolą mu sprostać wymaganiom stawianym przez te bodźce; 3) wymagania te są dla niego wyzwaniem wartym wysiłku i zaangażowania ${ }^{18}$.

Na poczucie koherencji składają się takie elementy, jak: zrozumiałość, zaradność, sensowność. Skorelowane ze sobą wszystkie komponenty warunkują stosowanie skuteczniejszych strategii radzenia sobie z problemami, co w konsekwencji sprzyja zachowaniu zdrowia, a także prawidłowych relacji $\mathrm{z}$ otoczeniem ${ }^{19}$.

Rozważając sytuację rodzeństwa osób z niepełnosprawnością w sytuacji pandemii koronawirusa, można uznać, że część z nich doświadcza kryzysu sytuacyjnego wynikającego z faktu nagłej nieoczekiwanej zmiany, która z jednej strony dotyczy zmiany organizacji dnia codziennego, z drugiej zaś przebywania ze swoim niepełnosprawnym rodzeństwem $\mathrm{w}$ zasadzie całe dnie. Może wpływać to na poczucie koherencji.

${ }_{17}$ J. Jezierska, Diagnoza w obszarze interwencji kryzysowej, s. 191-204.

18 A. Antonovsky, Rozwiktanie tajemnicy zdrowia. Jak radzić sobie ze stresem i nie zachorować, Warszawa 2005, s. 34.

${ }^{19}$ P. Jurkiewicz, Rodzeństwo osób z niepetnosprawnością intelektualną. W drodze od osamotnienia do zaradności, zrozumiałości i sensowności, Warszawa 2017. 
Badania poszukujące związku między stresem, posiadanymi zasobami radzenia sobie $\mathrm{z}$ nim a poczuciem koherencji, przeprowadzone $\mathrm{w}$ grupie nastolatków będących rodzeństwem osób z autyzmem, wykazały, że rodzeństwo dzieci o dużym nasileniu objawów miały więcej zachowań problemowych, tym samym niższy poziom przystosowania. Ponadto, wpływało to także negatywnie na budowanie relacji z rówieśnikami, a także z rodziną i niepełnosprawnym rodzeństwem ${ }^{20}$. Można więc domniemać, że sytuacja pozostania w domu z niepełnosprawnym bratem czy siostrą, bez większej możliwości wyjścia, zorganizowania czasu poza nim, może odgrywać znaczącą rolę w obniżeniu poczucia koherencji.

\section{Specyficzna sytuacja rodzeństwa osób z niepełnosprawnością w okresie epidemii}

Sytuacja pandemii wirusa SARS-CoV-2, który wywołuje chorobę COVID-19, spowodowała kryzys w różnych sferach życia społecznego, w tym również rodzinnego. Ta nagła zaskakująca rzeczywistość wywołująca lęk i dezintegrująca codzienne życie ma ogromne znaczenie dla funkcjonowania poszczególnych osób w rodzinie. Wpływa na wzajemne relacje czy sposób spędzania czasu. W tej zmienionej trudnej rzeczywistości znalazło się również rodzeństwo osób z niepełnosprawnością. Rodzeństwo, które $\mathrm{z}$ uwagi na swoją specyficzną sytuację $\mathrm{i}$ tak jest obarczane wieloma sytuacjami kryzysowymi.

Jak wiadomo, sposób przeżywania kryzysu jest determinowany trzema głównymi czynnikami: kontekstem społecznym, kontekstem rodzinnym i cechami osobowościowymi danej jednostki. Z uwagi na zróżnicowaną sytuację kryzys jest przeżywany przez dzieci i młodzież w różny sposób, w zależności od układu wyżej wymienionych czynników: czy są to osoby z dużymi zasobami osobowościowymi, które ułatwiają im radzenie sobie z kryzysem, czy na odwrót. Czy osoby te mają silne oparcie w rodzinie czy nie. Czy mają one silne oparcie w rodzinie, ale charakteryzują się deficytami społecznymi i osobistymi. Czy są to osoby z dużymi zasobami społecznymi, rodzinnymi i osobistymi, które pozwalają im na poradzenie sobie z kryzysem. W związku ze specyfiką funkcjonowania poszczególnych osób należy zdawać sobie sprawę, że radzenie sobie z sytuacją pandemii jest bardzo złożone i zróżnicowane. W szczególnie trudnej sytuacji znajdują się dzieci i młodzież, która doświadcza nie tylko kryzysu związanego

${ }^{20}$ L.O. Smith i in., Predictors of sense of coherence in typically developing adolescent siblings of individuals with autism spectrum disorder, Journal of Intellectual Disability Research, 2015, 59, s. 26-38. 
z epidemią, ale jednocześnie innych kryzysów, na przykład wewnętrznego, rodzinnego. Niezbędne może okazać się wówczas zastosowanie rozwiązań z zakresu interwencji kryzysowej ${ }^{21}$. W sytuacji takiej może znajdować się właśnie rodzeństwo osób z niepełnosprawnością, które z uwagi na swoją specyficzną rzeczywistość najczęściej podlega też innym kryzysom. Stan epidemii może pogłębiać kryzys w rodzinie, z uwagi na podwyższony poziom lęku u wszystkich jej członków. W przypadku rodziców lęk ten może być szczególnie nasilony z uwagi na występującą u większości osób z niepełnosprawnością obniżoną odporność, ale także obawę przed utratą pracy. Do tego sytuacja epidemii jest często niezrozumiała przez osoby z niepełnosprawnością. Zmiana ich rytmu funkcjonowania, izolacja, napięcie emocjonalne pozostałych członków rodziny, może powodować u nich nasilenie zachowań problemowych, które w czasie izolacji są szczególnie uciążliwe dla reszty rodziny. Wszystko to pogłębia trudną sytuację rodzeństwa osób $\mathrm{z}$ niepełnosprawnością. Muszą się oni uporać $\mathrm{z}$ własnym lękiem związanym z panującą chorobą, ale także z innymi kryzysami wywołanymi specyficzną sytuacją rodzinną. Nagromadzenie zachowań trudnych niepełnosprawnego barta czy siostry i nachodząca na to izolacja, która powoduje brak możliwości oderwania się od tej kryzysowej sytuacji, może powodować, że obciążenie dla tych dzieci i młodzieży jest zbyt duże. Ponadto, rodzeństwo osób z niepełnosprawnością zostało obecnie pozbawione możliwości realizowania siebie w różnych formach aktywności, na przykład szkolnej sportowej, które stanowiły dla nich swoisty wentyl bezpieczeństwa. Pozwalały na rozładowanie napięcia związanego $\mathrm{z}$ trudnościami przeżywanymi $\mathrm{w}$ domu. Sytuacja pandemii tworzy też wiele obszarów, które mogą poszerzać ich obowiązki w stosunku do niepełnosprawnego rodzeństwa. Takim obszarem jest nauczanie zdalne, które w przypadku osób z niepełnosprawnością wymaga wsparcia, choć nie należy zapominać, że często osoby w normie też samodzielnie nie potrafią sobie poradzić z tą nową formą nauki. Praca zdalna w domu rodziców wymusza też zajęcie się wzajemne dzieci, aby rodzice mogli realizować zadania zawodowe. Zwiększony zakres obowiązków, częstsze doświadczania sytuacji trudnych ze strony rodzeństwa z niepełnosprawnością, mniejsza ilość czasu poświęcanego przez rodziców, lęk związany z chorobą, trudności związane z nową formą edukacji, nachodząca na to izolacja wiążąca się z brakiem możliwości odreagowania napięcia $\mathrm{w}$ bezpieczny sposób może powodować, że dzieci te mogą przestać radzić sobie $\mathrm{z}$ kryzysem. Zagrożenie przeciążeniem emocjonalnym jest $\mathrm{w}$ przypadku rodzeństwa osób z niepełnosprawnością bardzo duże, w związku z czym

${ }^{21}$ W. Poleszak, J. Pyżalski, Relacje przede wszystkim - nawet jeśli obecnie jedynie zapośredniczone, [w:] Edukacja w czasach pandemii wirusa COVID-19. Z dystansem o tym, co robimy obecnie jako nauczyciele, red. J. Pyżalski, Warszawa 2020, s. 9-10. 
należy udzielić im wsparcia, dopóki na to wsparcie nie jest za późno. Należy pamiętać, że kryzys - jako nieodzowny element życia każdego człowieka - może być niebezpieczny i prowadzić do wielu poważnych konsekwencji.

\section{Wspieranie}

Myśląc o wspieraniu rodzeństwa osób z niepełnosprawnością w sytuacji kryzysowej, jaką jest pandemia wirusa SARS-CoV-2 wywołującego chorobę COVID-19, należy rozważyć z jednej strony wsparcie całej rodziny, z drugiej zaś - samego brata czy siostry osoby z niepełnosprawnością. Część dzieci i młodzieży wychowujących się razem $\mathrm{z}$ niepełnosprawnym rodzeństwem objęte jest wsparciem systemowym, często wieloletnim. Takie wsparcie daje możliwość, po pierwsze, szybkiej reakcji rodziców w sytuacji kryzysowej, po drugie - uczy zdrowe rodzeństwo zauważania sygnałów, które mogą oznaczać pogorszenie się stanu emocjonalnego i psychicznego, a co za tym idzie - uczy proszenia o pomoc.

Warto tutaj podkreślić, że rodzeństwo samo zauważa, że potrzebne jest $\mathrm{mu}$ wsparcie $\mathrm{w}$ rozwiązywaniu różnych sytuacji trudnych. Wsparcie to dotyczy przede wszystkim strategii radzenia sobie ze stresem, co wpływa na zwiększenie poczucia koherencji u nich ${ }^{22}$.

W sytuacji braku kontroli nad bodźcami dopływającymi z zewnątrz, a także poczucia niezbyt szybkiego rozwiązania problemu, jakim jest przeciążenie obecnością niepełnosprawnego rodzeństwa i pojawienie się nagłych sytuacji kryzysowych z objawami silnego stresu, lęków, niepokoju, a czasami myśli samobójczych, konieczne jest włączenie oddziaływań na drodze interwencji kryzysowej. Koncentruje się ona na pomaganiu osobie w uświadomieniu sobie występowania zaburzeń równowagi i dysfunkcji w obszarach: emocjonalnym, poznawczym i behawioralnym, które wywołane zostały wydarzeniem krytycznym. Wskazuje także na możliwości uzyskania pomocy i wsparcia w różnych aspektach, między innymi medycznych, społecznych, czy instytucjonalnych ${ }^{23}$.

W przypadku rodzeństwa osób niepełnosprawnych, w omawianej sytuacji rodzajem interwencji, jaka powinna być podjęta, jest interwencja indywidualna, skierowana, jak wskazuje D. Kubacka-Jasiecka, na pomoc w sytuacji traumatycznej natychmiastowej zagrażającej zdrowiu i życiu osoby, ale także na grupy tak zwanego ryzyka kryzysowego.

${ }^{22}$ D. Mungo i in., Impairment of quality of life in parents of children and adolescents with pervasive developmental disorder, Health and Quality of Life Outcomes, 2007, 5, s. 22-29.

${ }^{23}$ D. Kubacka-Jasiecka, P. Passowicz, Kryzys i interwencja - spojrzenie z perspektywy ekologiczno-systemowej, [w:] Interwencja kryzysowa. Konteksty indywidualne $i$ społeczne, red. D. Kubacka-Jasiecka, P. Passowicz, Kraków 2016, s. 7-26. 
$\mathrm{Na}$ interwencję indywidualną powinna złożyć się dokładna diagnoza kryzysu, następnie etap nawiązania kontaktu z osobą, identyfikacja problemów źródłowych, a dalej pomoc w radzeniu sobie z uczuciami wzbudzanymi przez kryzys, rozważanie rozwiązań kryzysu oraz formułowanie działań przyszłościowych oraz ich monitorowanie.

Aby interwencja indywidualna miała szansę powodzenia, $\mathrm{w}$ wielu podejściach do tego typu oddziaływań włącza się także nurt interwencji wielostronnej i interdyscyplinarnej, a więc skierowana jest na szeroki kontekst społeczny, w którym funkcjonuje rodzeństwo osoby z niepełnosprawnością ${ }^{24}$. Na tę część składa się między innymi aktywizacja wsparcia społecznego środowiska lokalnego, opieka medyczna i psychiatryczna, organizacja życia codziennego, czy zapewnienie możliwości informacji bądź konsultacji.

Tak więc, w sytuacji kryzysowej rodzeństwa osób z niepełnosprawnością w czasie pandemii COVID-19 konieczne są:

- stały kontakt online bądź telefoniczny dzieci i młodzieży z pedagogiem szkolnym bądź psychologiem, psychoterapeutą, który będzie potrafił zauważyć niepokojące symptomy;

- stały kontakt online bądź telefoniczny rodziców z pedagogiem bądź psychologiem, psychoterapeutą, który będzie w stanie wskazać rodzinie, w jaki sposób organizować życie codzienne, a także na co zwracać uwage w zachowaniu pełnosprawnego dziecka;

- podejmowanie kontaktu z psychiatrą w sytuacji pogarszania się stanu psychicznego zdrowego rodzeństwa;

- udzielanie wskazówek dotyczących organizacji czasu na terenie domu, dawanie przestrzeni pełnosprawnemu dziecku na tyle, ile jest to możliwe do możliwości "odcięcia” się od codziennych czynności związanych z opieką, pielęgnacją i edukacją niepełnosprawnego rodzeństwa, a także możliwością organizacji czasu wolnego we własnej przestrzeni;

- motywowanie do utrzymywania kontaktów online z rówieśnikami; ważna jest $\mathrm{w}$ tym aspekcie duża czujność i uważność związana z oceną kontaktów online $\mathrm{z}$ rówieśnikami $\mathrm{w}$ celu przeciwdziałania cyberprzemocy;

- motywowanie do dalszego rozwijania własnych pasji i zainteresowań, a w razie braku możliwości realizowania ich na terenie domu - wskazanie innych możliwości;

- udzielanie informacji o metodach aktywnego spędzania czasu z niepełnosprawnym rodzeństwem;

- udzielanie informacji na temat stanu emocjonalnego i psychicznego niepełnosprawnego rodzeństwa, a także strategii radzenia sobie głównie z zachowaniami problemowymi;

${ }^{24}$ D. Kubacka-Jasiecka, Interwencja w społeczności - trzeci nurt interwencji kryzysowej, [w:] Tamże, s. 27-41. 
- włączanie dzieci i młodzieży do grup wsparcia w formie online, dających możliwość rozmowy, przekazywania własnych emocji, opisu trudności, a także wsparcia w rozwiązywaniu codziennych sytuacji trudnych; motywowanie do utrzymywania kontaktu z tego typu grupami;

- dawanie czasu dla bycia tylko z własnym rodzicem, pełnej jego uwagi i zaangażowania, choćby miało to się odbywać w krótkich interwałach czasowych.

Działania te są konieczne $\mathrm{w}$ celu dodatkowego wsparcia rodzeństwa osób z niepełnosprawnością, które w czasie pandemii pogłębiło swoją często kryzysową sytuację, w jakiej się znajduje, przez co wiele wcześniej wypracowanych sposobów radzenia sobie z nią mogło zacząć zawodzić. W związku $\mathrm{z}$ tym niezmiernie ważne jest $\mathrm{w}$ tej sytuacji wspieranie całego systemu rodzinnego, aby każde ogniwo miało szansę przetrwać ten czas, znaleźć w sobie zasoby zmagazynowane na walkę z przeciwnościami losu tak, aby każdy wyszedł z tej sytuacji w dobrej kondycji emocjonalnej, psychicznej i społecznej.

\section{Zamiast podsumowania}

Jak potrzebne jest wsparcie rodzeństwa osób z niepełnosprawnością mogą świadczyć wypowiedzi tych dzieci, odnoszące się do sytuacji kryzysowej związanej z pandemią. Poniższe wypowiedzi uzyskano podczas przeprowadzonych wywiadów z rodzeństwem dzieci z niepełnosprawnością.

Teraz jest nie do wytrzymania. Jesteśmy cały czas razem, nie ma gdzie uciec. Mój brat ciagle wrzeszczy, marudzi, zaczepia się czy bije. Mam go dosyć, rodzice też (wypowiedź siostry młodszego brata z zespołem Downa).

Nigdy nie było łatwo, ale teraz, wie Pani, wszyscy sa zdenerwowani caty czas. Mój brat jest jeszcze bardziej trudny, a ja muszę caty czas z nim być, go stuchać. Wynosić się do kuchni jak ma rehabilitacje, tak normalnie bytam w szkole, a teraz tylko podaj to, podaj tamto, przypilnuj go i tak w kótko. A gdzie ja, nie żebym narzekała, ale wie Pani (wypowiedź siostry młodszego brata z mózgowym porażeniem dziecięcym sprzężonym z niepełnosprawnością intelektualną).

Sytuacja zamknięcia wiele zmienita, wszystkie znane schematy Bartka zostaty mu zabrane, co na początku powodowało rozdrażnienie u brata, nie mógł się na niczym skupić, czasem płakat, niszczył rzeczy, chciat iść do szkoty. Kolejna trudność jest związana z tym, że czas, który Bartek spędzat w szkole, mama mogła odpoczać, lub w spokoju zrobić zakupy. Musiatyśmy się podzielić obowiazkami: opieka nad Bartkiem i organizowanie mu czasu, terapia, zakupy, sprzatanie, moje studia. Z czasem wypracowaliśmy sobie nowy plan dnia tak, żeby każdy miat czas na wszystko. Ostatnie tygodnie Bartek radzi sobie naprawdę coraz lepiej, chyba się przyzwyczait (wypowiedź siostry nastolatka z autyzmem). 


\section{BIBLIOGRAFIA}

Antonovsky A., Rozwikłanie tajemnicy zdrowia. Jak radzić sobie ze stresem i nie zachorować, Instytut Psychiatrii i Neurologii, Warszawa 2005.

Badura-Madej W., Podstawowe pojęcia teorii kryzysu i interwencji kryzysowej, [w:] Wybrane zagadnienia interwencji kryzysowej. Poradnik dla pracowników socjalnych, red. W. Badura-Madej, Wydawnictwo Naukowe „Śląsk”, Katowice 1999.

Clarke S.A., Davies H., Jenney M., Glaser A., Eiser C., Parental communication and children's behaviour following diagnosis of childhood leukaemia, Psycho-Oncology, 2005, 14.

Dołęga Z., System rodzinny a samotność dzieci i młodzieży, [w:] Kultura pedagogiczna wspótczesnej rodziny, red. J. Cichla, J. Herberger, B. Skwarek, Wydawnictwo Druk-Ar, Głogów 2010.

Fisman S., Wolf L., Ellison D., Freeman T., A longitudinal study of siblings of children with chronic disabilities, Canadian Journal of Psychiatry, 2000, 45(4).

Gerrig R.J., Zimbardo P.G., Psychologia i życie, Wydawnictwo Naukowe PWN, Warszawa 2006.

James R.K., Gilliland B.E., Strategie interwencji kryzysowej, Wydawnictwo Parpa, Warszawa 2004.

Jezierska J., Diagnoza w obszarze interwencji kryzysowej, Lubelski Rocznik Pedagogiczny, 2019, XXXVIII, 2.

Jurkiewicz P., Rodzeństwo osób z niepetnosprawnościa intelektualną. W drodze od osamotnienia do zaradności, zrozumiałości i sensowności, Wydawnictwo Akademii Pedagogiki Specjalnej, Warszawa 2017.

Kaminsky L., Dewey D., Psychosocial adjustment in siblings of children with autism, Journal of Child Psychology and Psychiatry and Allied Disciplines, 2002, 43, 2.

Kubacka-Jasiecka D., Passowicz P., Kryzys i interwencja - spojrzenie z perspektywy ekologiczno-systemowej, [w:] Interwencja kryzysowa. Konteksty indywidualne i społeczne, red. D. Kubacka-Jasiecka, Krakowska Akademia im. Andrzeja Frycza Modrzewskiego, Kraków 2016.

Ley K., Rodzeństwo - miłość, nienawiść, solidarność, Instytut Wydawniczy PAX, Warszawa 2004.

McHale S.M., Updegraff K.A., Feinberg M.E., Siblings of Youth with Autism Spectrum Disorders: Theoretical Perspectives on Sibling Relationships and Individual Adjustment, Journal of Autism and Developmental Disorders, 2016, 46(2).

Prata J., Lawson. W., Coelho R., Stress factors in parents of children on the autism spectrum: an integrative model approach, International Journal of Clinical Neurosciences and Mental Health, 2019, 6, 2.

Pisula E., Rodzice i rodzeństwo dzieci z zaburzeniami rozwoju, Wydawnictwo Uniwersytetu Warszawskiego, Warszawa 2007.

Poleszak W., Pyżalski J., Relacje przede wszystkim - nawet jeśli obecnie jedynie zapośredniczone, [w:] Edukacja w czasach pandemii wirusa COVID-19. Z dystansem o tym, co robimy obecnie jako nauczyciele, red. J. Pyżalski, Wydawnictwo Edukacyjne, Warszawa 2020.

Sharpe D., Rossiter L., Siblings of Children with a Chronic Illness: A Meta-Analysis, Journal of Pediatric Psychology, 2002, 8.

Skłodowski H., Psychologiczne wyzwania kryzysu, [w:] Człowiek w kryzysie - psychospołeczne aspekty kryzysu, red. H. Skłodowski, Wydawnictwo SWSPiZ, Łódź 2010.

Smith L.O., Elder J.H., Storch E.A., Rowe M.A., Predictors of sense of coherence in typically developing adolescent siblings of individuals with autism spectrum disorder, Journal of Intellectual Disability Research, 2015, 59, 1. 
Sygulska K., Krupska M., Kryzys w życiu człowieka, Praca Socjalna, 2019, 6.

Vermaes I.R., Susante A.M., Bakel H.J., Psychological Functioning of Siblings in Families of Children with Chronic Health Conditions: A Meta-Analysis, Journal of Pediatric Psychology, 2012, 37.

Walęcka-Matyja K., Przybylak A., Sytuacja życiowa rodzeństwa osób z niepetnosprawnościa intelektualna, [w:] Rozwój i jego wspieranie w perspektywie rehabilitacji i resocjalizacji, red. D. Müller, A. Sobczak, Wydawnictwo Uniwersytetu Łódzkiego, Łódź 2013.

Włodarczyk E., Zdarzenie losowe i sytuacja kryzysowa, [w:] Człowiek wobec krytycznych sytuacji $\dot{z}$ yciowych. Z teorii i praktyki pracy socjalnej, red. E. Włodarczyk, I. Cytlak, Wydawnictwo Naukowe UAM, Poznań 2011.

Żyta A., Rodzeństwo osób z głębszą niepetnosprawnościa intelektualna, Oficyna Wydawnicza Impuls, Kraków 2004.

Żyta A., Badania nad rodzeństwem osób z niepetnosprawnościa intelektualna w perspektywie zmian - przeszłość, teraźniejszość, przyszłość, [w:] Pedagogika specjalna: różne poszukiwania - wspólna misja, red. M. Bielska-Łach, Wydawnictwo Akademii Pedagogiki Specjalnej im. Marii Grzegorzewskiej, Warszawa 2009.

Żyta A., Rodzeństwo osób z niepetnosprawnością. Wspólne dorastanie. Dylematy. Wsparcie, [w:] Rodzeństwo osób z niepetnosprawnościa, red. J. Koral, Stowarzyszenie Rodzin i Opiekunów Osób z Zespołem Downa Bardziej Kochani, Warszawa 2013. 